\title{
Precipitation chemistry in East Asia
}

\author{
Shin-ichi Fujita ${ }^{\mathrm{a}, *}$, Akira Takahashi ${ }^{\mathrm{a}}$, Jian-Hua Weng ${ }^{\mathrm{b}}$, Lian-Fen Huang \\ Hui-Kang Kim ${ }^{c}$, Cheng-Kang Lid ${ }^{\mathrm{d}}$, Frank T.C. Huang ${ }^{\mathrm{d}}$, Fu-Tien Jeng ${ }^{\mathrm{e}}$ \\ ${ }^{a}$ Komae Research Laboratory, Central Research Institute of Electric Power Industry, 2-11-1 Iwado-kita, Komae-Shi, Tokyo 201-8511, Japan \\ ${ }^{\mathrm{b}}$ Institute of Water Conservancy and Hydroelectric Power Research, 20 Chegongzhuang West Road, Beijing 100044, \\ People's Republic of China \\ ${ }^{c}$ Department of Environmental Engineering, Kon-Kuk University, 93-1, Mojin-Dong, Kwangjian- Ku, Seoul 133-701, Korea \\ ${ }^{\mathrm{d}}$ Testing Laboratory, Taiwan Power Company, 39 Chung-Hsiao E. Road, 6, Taipei, Taiwan \\ ${ }^{\mathrm{e}}$ Graduate Institute of Environmental Engineering, National Taiwan University, R303, No.71, Chou-San Road, Taipei, Taiwan
}

Received 28 August 1998; received in revised form 5 January 1999; accepted 6 May 1999

\begin{abstract}
The chemical composition of precipitation in East Asia was analyzed on the basis of the results of cooperative monitoring performed during the period from 1992 to 1993 . The wet deposition of soluble ions was characterized by two major factors; the geographical distribution of precursor production through natural and anthropogenic activities, and the meteorological conditions such as wind system and rainfall pattern due to the Asian monsoon. Although northeastern China had the largest anthropogenic emission source, precipitation with relatively high $\mathrm{pH}$ value was observed. At islands in the northern Pacific far from major anthropogenic emission sources, precipitation with relatively low $\mathrm{pH}$ value was observed. It was suggested that ammonia and calcium were constantly produced in the continent, and that the higher concentrations of these bases in the atmosphere were incorporated into precipitation elements and neutralized the acidity due to $\mathrm{H}_{2} \mathrm{SO}_{4}$ and $\mathrm{HNO}_{3}$ from fossil fuel combustion. The ratio of $\left[\mathrm{nssCa}^{2+}+\mathrm{NH}_{4}^{+}\right] /\left[\mathrm{nssSO}_{4}^{2-}+\mathrm{NO}_{3}^{-}\right]$in precipitation was highest on the continent, moderate in the Korean Peninsula and the Japanese Islands, and lowest in the northern Pacific; in other words, this ratio decreased as the distance from the continent increased. In the central region of East Asia, which is affected by both continental cold, dry air masses and subtropical warm, humid air masses, the frequency distribution of $\mathrm{pH}$ of precipitation showed a bimodal pattern in which unimodal patterns of northern China and that of the Japanese Islands were superimposed. The wet deposition of $\mathrm{nssSO}_{4}^{2-}, \mathrm{NO}_{3}^{-}, \mathrm{nssCa}^{2+}$, and $\mathrm{NH}_{4}^{+}$showed relatively small differences between the sites, while that of $\mathrm{Na}^{+}$and $\mathrm{Cl}^{-}$, relatively large differences between the sites, reflecting the field of ionic concentration and amount of precipitation in East Asia. (C) 1999 Elsevier Science Ltd. All rights reserved.
\end{abstract}

Keywords: Acid rain; Precipitation chemistry; Wet deposition; Emission; East Asia

\section{Introduction}

Research on precipitation chemistry in East Asia was initiated by the European agricultural chemists in the second half of the 19th century. Such research was stimulated by J. von Liebig, who postulated that sufficient amounts of nitrogen compounds for the growth of agricultural plants were supplied from the atmosphere.

* Corresponding author.
Miller (1913) summarized precipitation chemistry data obtained up to the beginning of the 20th century from various sites around the world, including Tokyo, Hanoi, Ceylon, Calcutta, Madras, and East Java. The data for Tokyo were collected between 1883 and 1885 under the guidance of $\mathrm{O}$. Kellner, who was invited from Germany (Kellner et al., 1886). His successors continued to conduct surveys at the Agricultural Experimental Stations between 1913 and 1933 and at the Kobe Marine Meteorological Observatory between 1935 and 1961 (Fujita, 1997; Ishikawa and Hara, 1997). 
In the mid 1970s, the World Meteorological Organization (WMO) set up precipitation chemistry monitoring sites at several locations in East Asia as the Background Air Pollution Monitoring Network (WMO, 1978). In the 1980s, industrial activity in East Asia increased significantly, and much attention was focused on qualitative changes in precipitation. In mainland China, the first national symposium on acid deposition was convened in Beijing in 1981. In 1982, national acid deposition projects covering the southwestern region were initiated by the National Environmental Protection Office (Zhao et al., 1988; Hao, 1991). In Korea, chemical analysis of precipitation began in Seoul and Ulsan in 1978. In addition, monitoring using automatic samplers was introduced by the Environmental Agency at 45 sites in 1983 (Lee, 1996; Kim, 1997). In Taiwan, monitoring of acid deposition was introduced at 10 sites by the Environmental Protection Administration in 1990, and two more sites were added in 1993 (Jeng, 1995; Chen et al., 1996). In Japan, surveys on "wet air pollution" were conducted in the metropolitan areas during the latter half of the 1970s (Okita, 1983). In 1983, acid deposition monitoring was introduced at 29 sites by the Environment Agency to collect fundamental data on the chemical composition of precipitation, and its effects on lakes and soils (JEA, 1987; Katoh et al., 1989; Hara, 1993).

Thus, each country or region in East Asia has been conducting its own research on precipitation chemistry. A critical review of worldwide acid deposition monitoring data, including that from East Asia before 1992, has been published (WMO, 1997). However, due to the limited quality and quantity of the available data on atmospheric acidity, it has so far been difficult to assess current or future levels of atmospheric acidity or sulfur and nitrogen fluxes to the surface (Ayers et al., 1997).

To compile and consolidate the results of the monitoring conducted by each organization, the Institute of Water Conservancy and Hydroelectric Power Research (IWHR), Kon-Kuk University (KKU), Taiwan Power Company (TPC), and the Central Research Institute of Electric Power Industry (CRIEPI) began cooperative precipitation chemistry monitoring, using identical wetonly samplers, in October 1990 (CRIEPI, 1993). In this study, on the basis of the data collected between June 1992 and May 1993, a period in which intense monitoring was conducted in East Asia, we analyzed factors affecting the chemical composition of precipitation in these regions.

\section{Methods of monitoring}

\subsection{Monitoring network}

The middle latitudes of the Northern Hemisphere, in which East Asia is located, exhibit wide variations in climate. For example, although located at similar latitudes, the Asian Continent, Korean Peninsula, Arcuate Islands, and north Pacific Ocean differ significantly in climate. The two important factors that affect the climates of East Asia are the wind system and the amount of precipitation. Several methods for classifying climates in East Asia have been proposed. Trewartha et al. (1967) classified East Asian climates into four types: Continental Warm Summer (DA), Continental Cool Summer (DB), Subtropical Humid (CF), and Steppe (BS). However, the detailed climatic conditions in each region are much more complex. Even within the same climate region, the factors that control rainfall may differ; for example, in the Korean Peninsula those on the Yellow Sea side differ from those on the Sea of Japan side, in Taiwan those on the Taiwan Strait differ from those on the Pacific Ocean side, and in the Japanese Islands those on the Sea of Japan side differ from those on the Pacific Ocean side.

Taking into consideration various climate conditions and geological factors, 18 sites that allowed easy collection of climatic data were selected. The central part of northern China was observed in this study. Southwestern China, where the effects of acid deposition on terrestrial ecosystems have been reported, was not included in this monitoring network. Fig. 1 shows the cooperative precipitation monitoring network as of May 1993 superimposed on a modification of the Köppen system of climate classification (Köppen, 1936; Trewartha et al., 1967).

\subsection{Monitoring method}

Precipitation samples were collected at 10-day intervals using a wet-only sampler. To prevent snow accumulation and freezing of the samplers, the driving part and funnel surface were heated automatically when the temperature fell below $0^{\circ} \mathrm{C}$. The amount of precipitation was measured using a tipping-bucket rain gauge.

The precipitation samples obtained from each site were transported to chemical laboratories in Beijing (IWHR), Seoul (KKU), Taipei (National Taiwan University), and Tokyo (CRIEPI), and each laboratory used its own analytical method. The analytical parameters included $\mathrm{pH}$, conductivity, $\mathrm{Na}^{+}, \mathrm{K}^{+}, \mathrm{Ca}^{2+}, \mathrm{Mg}^{2+}, \mathrm{NH}_{4}^{+}$, $\mathrm{SO}_{4}^{2-}, \mathrm{NO}_{3}^{-}$, and $\mathrm{Cl}^{-}$. Since there was no standard solution for chemical analysis of precipitation over East Asia, identical precipitation samples collected in Japan were sent to each laboratory to verify the conformity of the analytical data. For conductivity and $\mathrm{pH}$ measurement, samples were analyzed without pretreatment. For other parameters, samples were filtered through a Millipore filter with a pore size of $0.45 \mu \mathrm{m}$ before analysis.

The accuracy of the data obtained for each parameter was confirmed using two indices, the ratio of TA (total anion) to TC (total cation) and the ratio of ECobs (measured conductivity) to ECcal (calculated conductivity), 


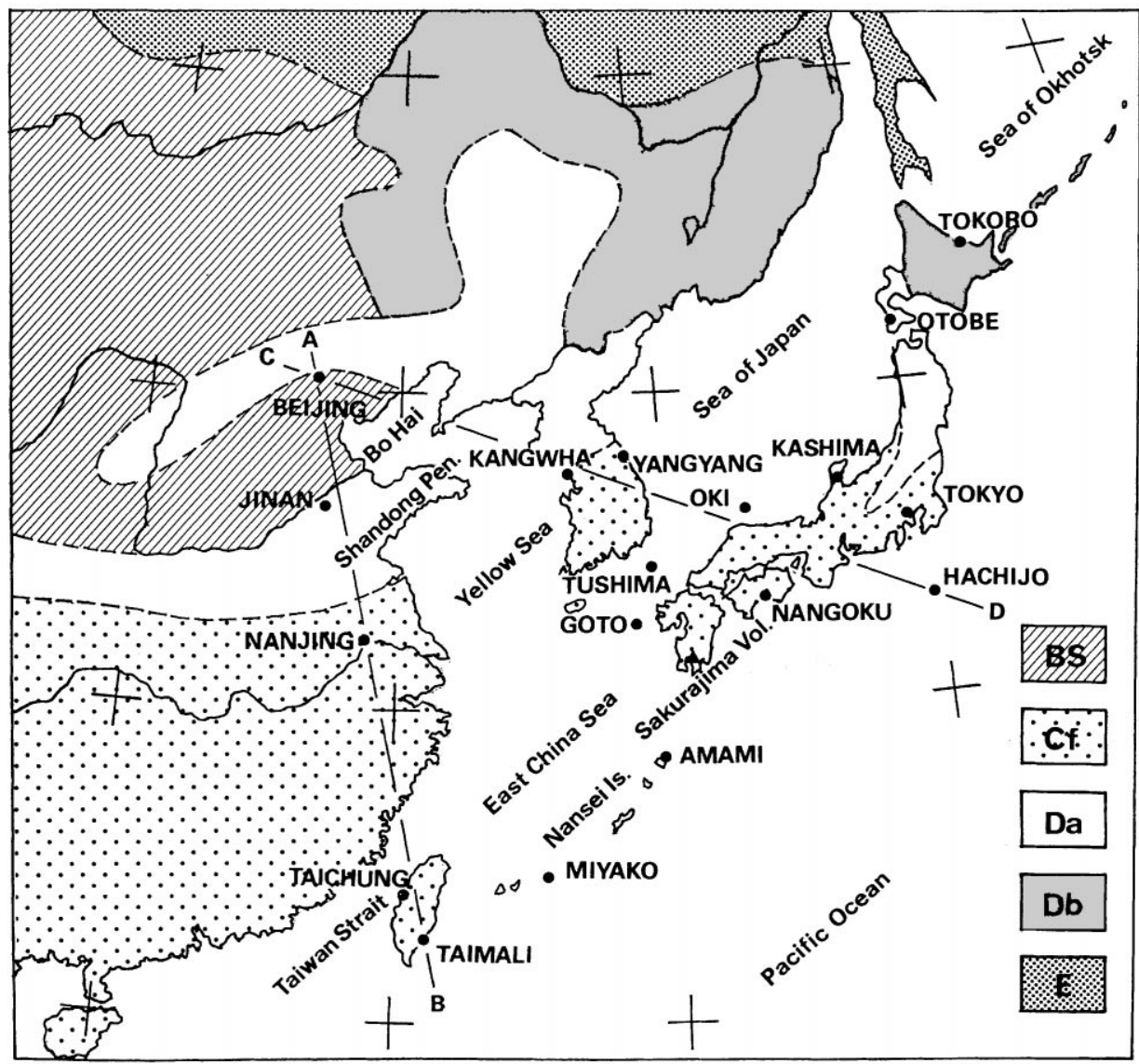

Fig. 1. Cooperative monitoring network for precipitation as of May 1993 superimposed on a modification of the Köppen system of climatic classification in East Asia.

based on the method proposed by Miles and Yost (1982). Screening was performed using a graph on which the values of TA/TC and ECobs/ECcal were plotted; the analysis data satisfying the condition that the deviations of both index values were within \pm 0.2 was identified. As described later, this checking method did not confirm a sufficient level of accuracy for the data obtained from northern China, where relatively high $\mathrm{pH}$ values were observed.

\section{Meteorological conditions}

In the summer of 1992, the North Pacific anticyclone extended over the Japanese Islands, resulting in a period of high temperature that lasted until the end of September. The monthly precipitation between June and September, which generally controls the annual precipitation in the Asian continent, was low on the Sea of the Japan side of western Japan where the stationary front had been less active, as well as in the region from southern Korea to the Shandong Peninsula in mainland China. In contrast, the monthly precipitation was higher than normal in the region from the Nansei islands of Japan to the eastern coast of China. The monthly precipitation during the autumn was lower than normal, due to the lower activity of the stationary front and the small number of northward-moving typhoons.

During the winter of 1992/1993, remarkably high temperatures prevailed from eastern Siberia to northern China. Northwestern China experienced a great sandstorm during the first half of May 1993 due to cyclones. Southern China received large amounts of rainfall during the spring and summer due to cyclones and typhoons. In Korea and Japan, significantly low temperatures were recorded; monthly average temperatures during the summer deviated from normal by almost $3^{\circ} \mathrm{C}$. The average amount of rainfall during the summer (June-September) at 11 meteorological stations located near monitoring sites, $873 \mathrm{~mm}$, was approximately $4 \%$ lower than normal. 
In contrast, the average amount of rainfall during the rest of the year (October-May) at 11 meteorological stations, $1075 \mathrm{~mm}$, was approximately $12 \%$ lower than normal.

During the monitoring period, eruptions occurred at 12 volcanoes in the Japanese Islands. Based on the data for volcanic activity at Sakurajima during the last decade, approximately $0.35 \mathrm{Tg} \mathrm{S} \mathrm{a}^{-1}$ of $\mathrm{SO}_{2}$, an amount almost equal to the total emission of $\mathrm{SO}_{2}$ from all stationary sources in Japan, may have been emitted. The yellow sand phenomenon, transport of soil particles from the Asian continent, were observed in Japan on 7 February, 1-3, April and 11 May 1993. In particular, the phenomenon observed at the beginning of April extended over most of Japan. The concentration of particulate calcium at six sites in Kangwha, Yangyang, Goto, Amami, and Oki was over three times the annual average value of $0.56 \mu \mathrm{g} \mathrm{m}^{-3}$ during this period (Fujita and Takahashi, 1994).

\section{Results}

\subsection{Chemical composition of precipitation in East Asia}

Table 1 shows the average concentration of ions in precipitation during a summer season (June-September, 1992) and a non-summer season (October, 1992-May, 1993), weighted with the amount of precipitation in the respective periods, for the 18 sites in East Asia. The concentrations of $\mathrm{SO}_{4}^{2-}, \mathrm{Ca}^{2+}$, and $\mathrm{NH}_{4}^{+}$were high at sites in northern China and low at sites in Japan. In contrast, concentrations of $\mathrm{Na}^{+}$and $\mathrm{Cl}^{-}$were high at sites in Japan and low at sites in China. Differences in the concentration of $\mathrm{K}^{+}, \mathrm{Mg}^{2+}$, and $\mathrm{NO}_{3}^{-}$between regions were low, relative to those of the above-mentioned ions. Generally, the ionic compositions at sites in Taiwan or Korea were intermediate between those obtained from mainland China and Japan. The total amount of ions was highest at Beijing and lowest at Taimali.

A comparison of TA and TC values showed that TA was generally identical to TC at all sites except for those in northern China. At sites in China, TA was generally lower than TC, and the difference between TA and TC increased with the increasing $\mathrm{pH}$ during the period from winter to spring. Summation of the concentration of $\mathrm{HCO}_{3}^{-}$, which equilibrates with $340 \mathrm{ppb}$ of $\mathrm{CO}_{2}$ in the atmosphere, brings TA to a level almost identical to that of TC.

When the origin of ions in precipitation was estimated using sodium as an index of sea salts, the ratio of sea salts/non-sea salts (ss/nss) differed significantly between monitoring sites. At sites on the Asian continent such as those in Beijing and Jinan, more than $85 \%$ of ions originated from non-sea salts. In contrast, at sites on the small island, such as Hachijo and Amami, more than $85 \%$ of ions originated from sea salts. The ratio of
$\mathrm{NO}_{3}^{-} / \mathrm{nssSO}_{4}^{2-}(\mathrm{N} / \mathrm{nssS})$, which have been used as an index for evaluating the condition of acidification, were between 0.14 (Nanjing) and 0.78 (Tokyo). This result agreed with those of the previous studies in which the contribution of sulfuric acid to acidification in China (Hao, 1991), and that of nitric acid to acidification in the metropolitan areas of Japan (Tamaki et al., 1991; Hara, 1993) were found to be significant.

\subsection{Frequency distribution of $p H$}

Fig. 2 shows frequency distributions of $\mathrm{pH}$ of precipitation observed at each site during the monitoring period. The annual average $\mathrm{pH}$ over the 18 sites was approximately 4.9. The maximum value of the annual average $\mathrm{pH}$ was observed at Jinan (pH: 6.1), and the minimum value, at Tokyo ( $\mathrm{pH}: 4.5)$. The maximum $\mathrm{pH}$ value during the 10-day period was observed at Beijing (pH: 8.0), and the minimum values, at Tokyo and Nangoku (pH: 3.9).

The frequency distribution of $\mathrm{pH}$ at most monitoring sites was similar to a unimodal distribution. However, the distribution pattern differed considerably between areas, as shown by the median $\mathrm{pH}$ value of 6.0 to 6.5 in northern China and that of 4.5-5.5 in Japan. We refer to the former pattern as type A, and the latter as type B. The distribution pattern of $\mathrm{pH}$ in Japan was similar to type "I", which was defined by Kitamura et al. (1991) based on the monitoring results obtained using bulk-samplers at 29 sites.

Based on a comparison of the $\mathrm{pH}$ frequency distributions at four sites located at almost the same longitude (line A-B in Fig. 1), namely Beijing (BJ), Jinan (JN), Nanjing (NJ) and Taichung (TC), the distributions at Beijing and Jinan were classified as type A, and that at Taichung as type B. In contrast, the distribution pattern at Nanjing, which lies between Jinan and Taichung, was a bimodal distribution (type $\mathrm{C}$ ) in which types $\mathrm{A}$ and $\mathrm{B}$ were superimposed. The median values were observed to lie in two ranges, $\mathrm{pH} 4.5-5.0$, and $\mathrm{pH}$ 6.0-7.0, and were similar to the median values of types $\mathrm{A}$ and $\mathrm{B}$, respectively. A distribution pattern with a broadened base similar to that of type $\mathrm{C}$ was also observed at Kangwha (KW), western coast of the Korean Peninsula.

\subsection{Wet deposition of ions}

Fig. 3 shows the wet deposition of sea salt and non-sea salt ions during a summer season and a non-summer season at each monitoring site. The wet depositions was high at sites on islands in the northern Pacific where the weather was warm and humid, and at sites facing the Sea of Japan where a large amount of snow fell in the winter season. However, the total wet deposition of ions was low at sites on the Asian continent where the weather was cold and dry. The annual average wet deposition originating from sea salts was $442 \mu \mathrm{eq} \mathrm{m}^{-2} \mathrm{a}^{-1}$ with 


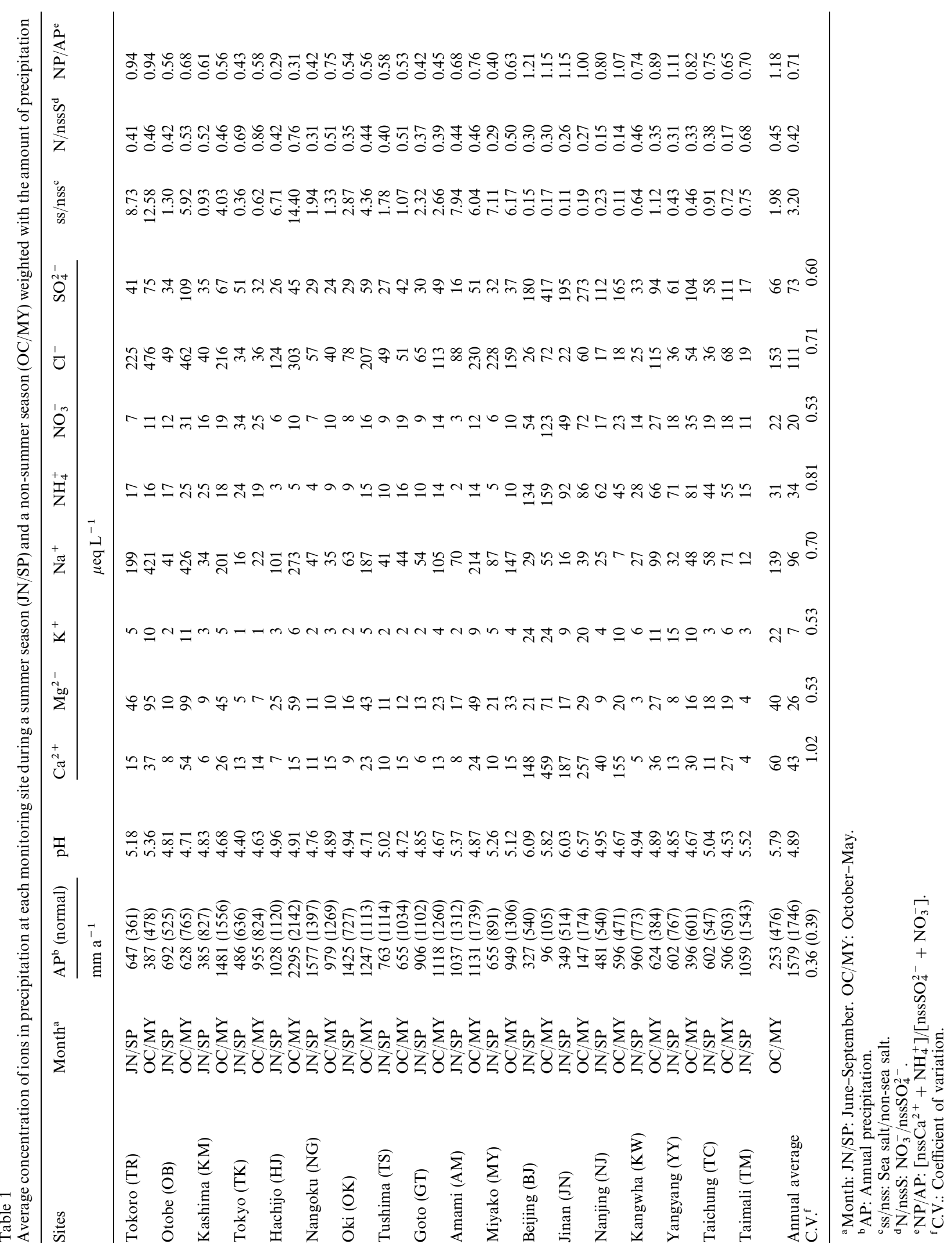




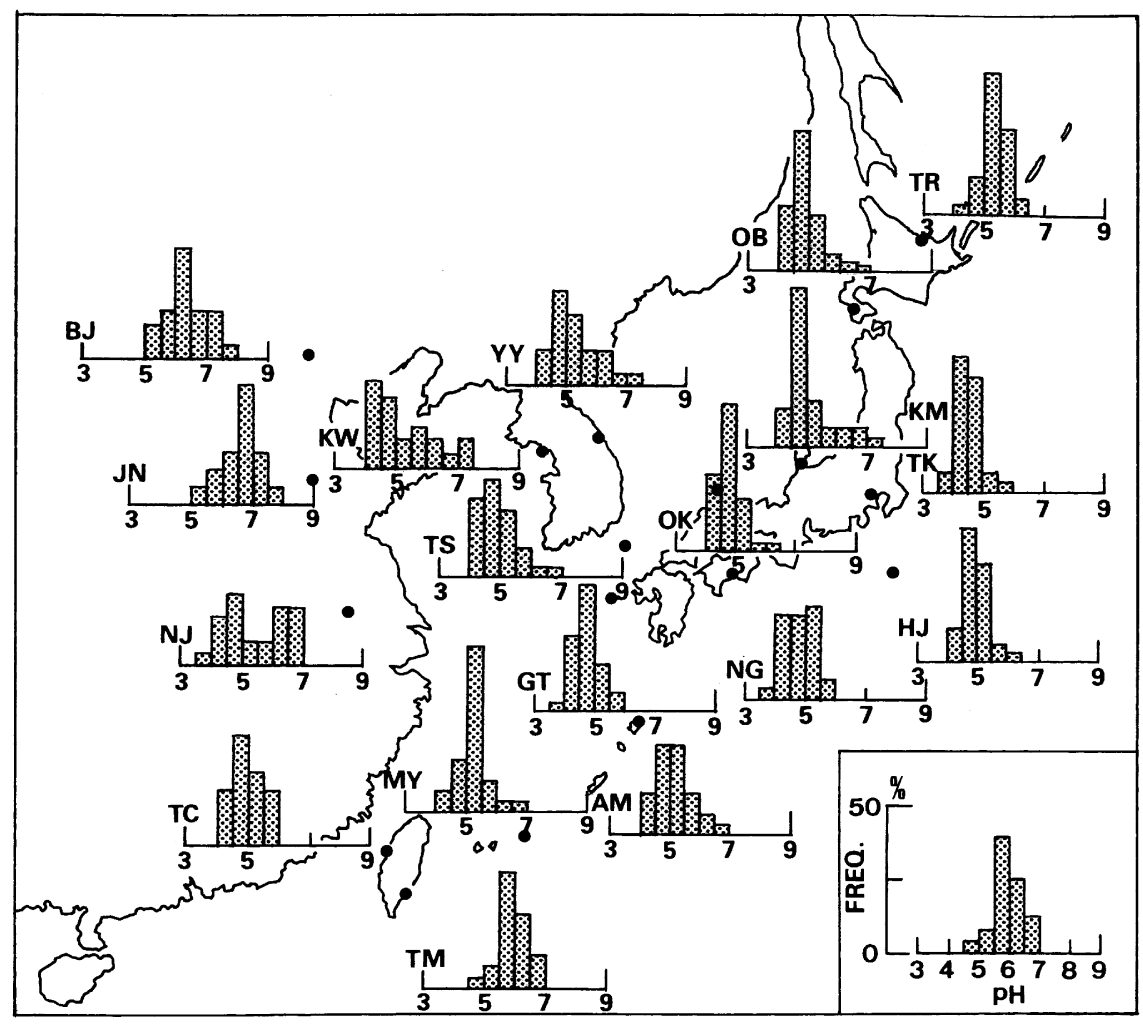

Fig. 2. Frequency distribution of $\mathrm{pH}$ of precipitation observed at each monitoring site during the period between June 1992 and May 1993.

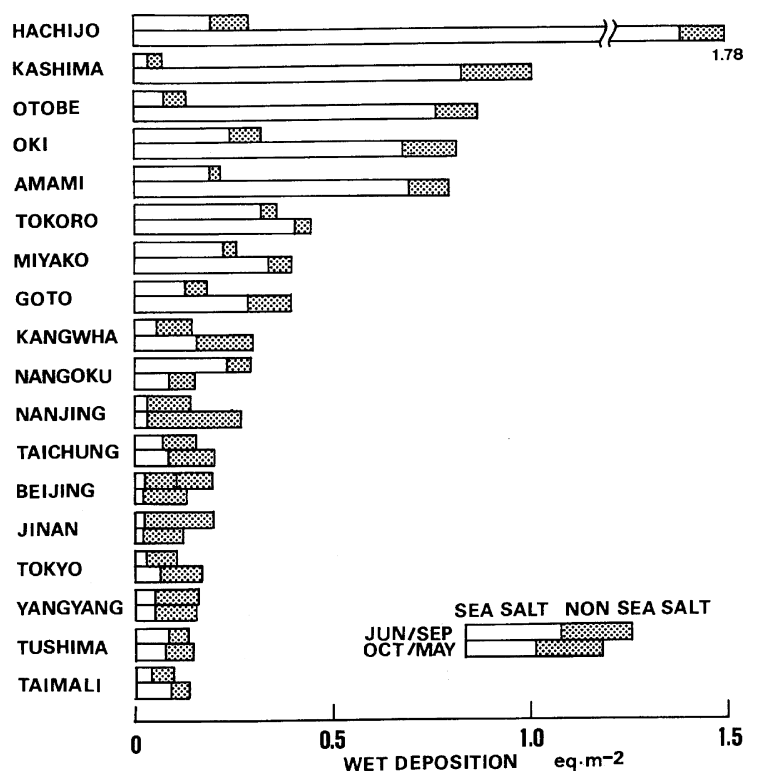

Fig. 3. Wet deposition of sea salt and non-sea salt ions at each monitoring site during a summer season (June 1992-September 1992) and a non-summer season (October 1992-May 1993). a coefficient of variation of 0.80 , and the differences between regions were marked. In contrast, the annual average wet deposition originating from non-sea salts was $186 \mu \mathrm{eq} \mathrm{m} \mathrm{m}^{-2} \mathrm{a}^{-1}$ with a coefficient of variation of 0.32 , and the differences between the regions were relatively low.

Fig. 4 shows seasonal variations in precipitation (upper) and wet deposition of sea salt and non-sea salt sulfate (lower) at Beijing, Kangwha, Kashima, and Hachijo which is located near the line C-D in Fig. 1. In general, in East Asia, the amount of precipitation is high in the warm season (April-September) and low in the cold season (October-March). For example, Beijing receives approximately $92 \%$ of its annual precipitation $(645 \mathrm{~mm})$ during the warm season and Tokyo, approximately $63 \%(1460 \mathrm{~mm})$. Exceptions are observed in the coastal areas of the Sea of Japan; for example, Kashima receives approximately $55 \%$ of its annual precipitation $(2383 \mathrm{~mm})$ during the cold season. The wet deposition of sulfate in the warm season was higher than that in the cold season at Beijing, and that in the cold season was higher than that in the warm season at Kashima, reflecting these seasonal variations of rainfall. The contribution of non-sea salt sulfate to total sulfate differed significantly 


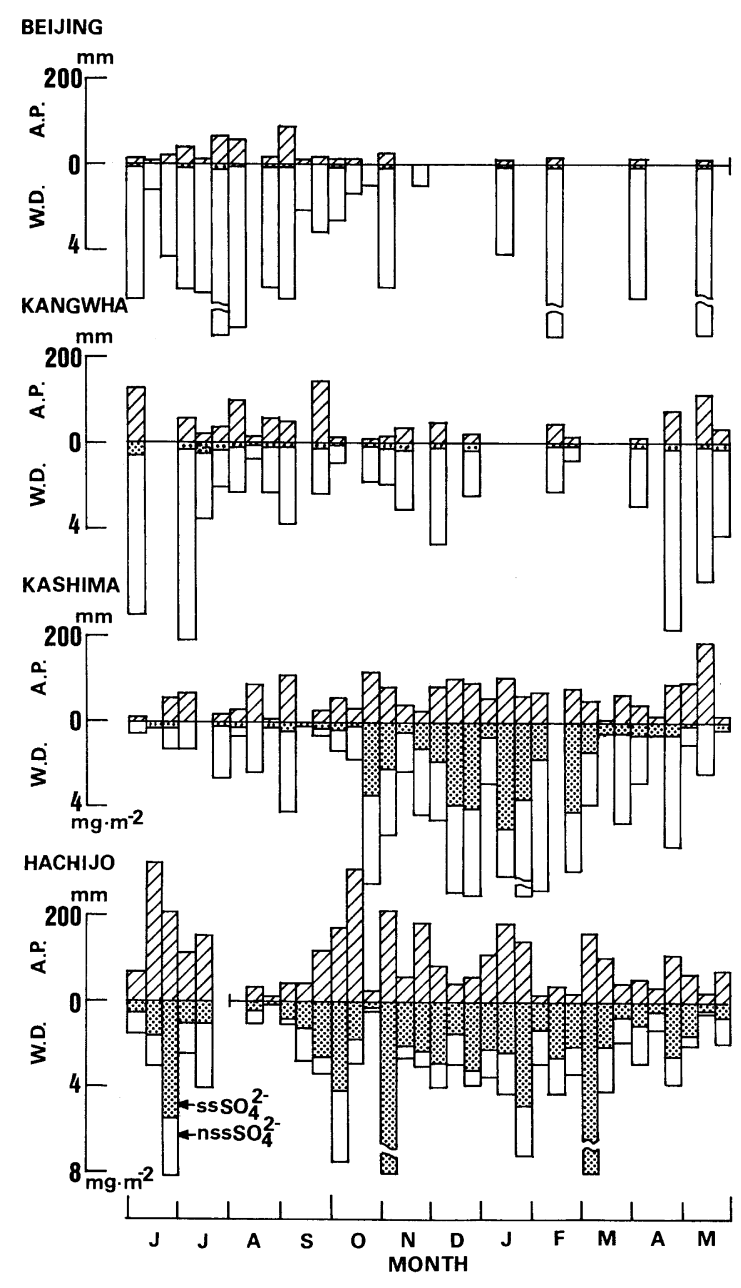

Fig. 4. Seasonal variations in the amount of precipitation (upper) and wet deposition (lower) of sea salt sulfate (hatched areas) and non-sea salt sulfate (clear areas) at Beijing, Kangwha, Kashima, and Hachijo.

between sites and seasons. The non-sea salt sulfate accounts for more than $95 \%$ of the total sulfate at Beijing, and that of more than $85 \%$, at Kangwha. This ratio was maintained throughout the year at both sites. The nonsea salt accounts for approximately $67 \%$ of the total sulfate at Kashima, and that of approximately $33 \%$ at Hachijo. This ratio tends to be high in the warm season and low in the cold season at both sites.

\section{Discussion}

Many studies have been performed in order to analyze the chemical composition of the precipitation in East Asia. Galloway et al. (1987) compared the chemical composition of the precipitation in China with that in the eastern United States and the remote areas of the Southern Hemisphere, and found that the wet deposition rate of sulfur in China was 7-130 times higher than that of the remote areas. They also suggested that the original acidity, defined as $\left[\mathrm{H}^{+}+\mathrm{Ca}^{2+}+\mathrm{NH}_{4}^{+}\right]$, is more than two orders of magnitude greater than the measured acidity $\left[\mathrm{H}^{+}\right]$in northern China. Kawaratani and Fujita (1990) monitored precipitation at six sites in southern Kyushu of Japan. They found that the $\mathrm{pH}$ of precipitation collected leeward of Sakurajima was extremely low, due to the incorporation of $\mathrm{HF}$ and $\mathrm{HCl}$ contained in the volcanic emissions. Dokiya et al. (1995) monitored precipitation at Hachijo and Amami, islands in the Pacific Ocean. They suggested that the wet deposition of $\mathrm{nssSO}_{4}^{2-}$ and $\mathrm{nssCa}^{2+}$ in the northern Pacific was influenced by the transport of sulfur and calcium from the Asian continent. Lee et al. (1989), Tsuruta (1989) and Nishikawa et al. (1992) analyzed ionic concentrations of precipitation during the occurrence of the yellow sand phenomenon. They found that the concentration of calcium was extremely high, which resulted in a high $\mathrm{pH}$ value in the early spring. Weng et al. (1993) analyzed the chemical composition of precipitation in the suburban areas of Beijing. They found that the concentrations of calcium and ammonia were markedly high and suggested that the chemical composition of the precipitation in the Beijing area was affected by the local environment. Yamaguchi et al. (1991), Ohizumi et al. (1991), Toriyama et al. (1991), and Fujita and Takahashi (1996) analyzed the chemical composition of precipitation at sites on the Sea of Japan side and found that the wet deposition of sulfate in winter was higher than that in summer. They speculated, based on trajectory analysis, budget analysis, and stable isotope analysis, that the high concentration was due to the long-range transport of sulfur from the Asian continent by seasonal winds.

The studies conducted during the last decade suggest that ionic concentrations in precipitation in East Asia are influenced mainly by two factors. The first factor is the meteorological conditions such as wind system and rainfall pattern due to Asian monsoons. The second factor is the geographical distribution of emission sources of chemical substance through natural and anthropogenic activities. To clarify factors affecting both temporal and spatial variations in the ionic concentrations, we considered the origin of each chemical substance and discussed the relationship between meteorological and geographical conditions and the wet deposition of ions in East Asia.

The origin of each chemical substance has not yet been clarified completely. However, based on the information obtained to date, the emission sources can be outlined as follows;

- Since the production of atmospheric sea salt particles is generally thought to be directly related to wind 
speed, those regions of ocean that experience relatively high wind speeds are also areas of high atmospheric sea salt production (Erickson and Duce, 1988). The most important region of sea salt production is thought to be the northwestern Pacific in the cold season and the central-western Pacific in the warm season.

- The Japanese Islands are one of the most active volcanic regions in the world. In the southwestern region of Japan, where Sakurajima is located, the annual emission of volcanic sulfur is $0.5 \mathrm{TgS} \mathrm{a}^{-1}$, which is equivalent to the level of anthropogenic emissions in Japan (Fujita et al., 1992). No active volcanoes exist on the Asian continent.

- Soil particles derived from the deserts of the Asian continent are frequently transported over the Japanese Islands to the central North Pacific during the spring (Ichikuni, 1978; Uematsu et al., 1983; Nishikawa et al., 1991; Hao, 1993). According to the results of the analysis performed in the deserts, atmospheric calcium exists mostly in the form of $\mathrm{CaCO}_{3}$, or sometimes in the form of $\mathrm{CaSO}_{4}$ (Hseung and Jackson, 1952; Okada and Kai, 1995).

- The annual emission of sulfur dioxide originating from fossil fuel combustion in East Asia is estimated to be about $12 \mathrm{TgS} \mathrm{a}^{-1}$. The emission in the coastal regions of Gulf of Bo Hai and the Yellow Sea is relatively high (Fujita et al., 1991; Akimoto and Narita, 1994; Ichikawa et al., 1997).

- The annual emission of nitrogen oxides originating from fossil fuel combustion is estimated to be about $4 \mathrm{TgN} \mathrm{a}^{-1}$. Although the geographical distributions of emission sources of nitrogen oxides and sulfur dioxide are almost the same, major sources are located separately within several metropolitan areas (Akimoto and Narita, 1994).

- The major anthropogenic sources of ammonia in East Asia are the application of chemical fertilizer, livestock, and energy consumption. The total ammonia emission in China accounts for $55 \%$ of the total emission in Asia (Zhao and Wang, 1994). The largest emission-producing region is considered to be the agricultural region of the Asian continent.

The $\mathrm{pH}$ of precipitation is generally determined by the nature and relative proportions of acids and bases in solution. According to the current understanding of atmospheric chemistry, $\mathrm{nssSO}_{4}^{2-}$ and $\mathrm{NO}_{3}^{-}$in precipitation exist as sulfuric acid and nitric acid when they are initially formed in the atmosphere. Fig. 5 shows annual emissions of sulfur dioxide per grid square as of 1990 (Ichikawa et al., 1997) superimposed on the geographical distribution of production sources of sea salt, volcanic sulfur, soil particles, and ammonia in East Asia. The regional emission sources of sulfur dioxide in East Asia are located in the eastern coastal regions of the continent.

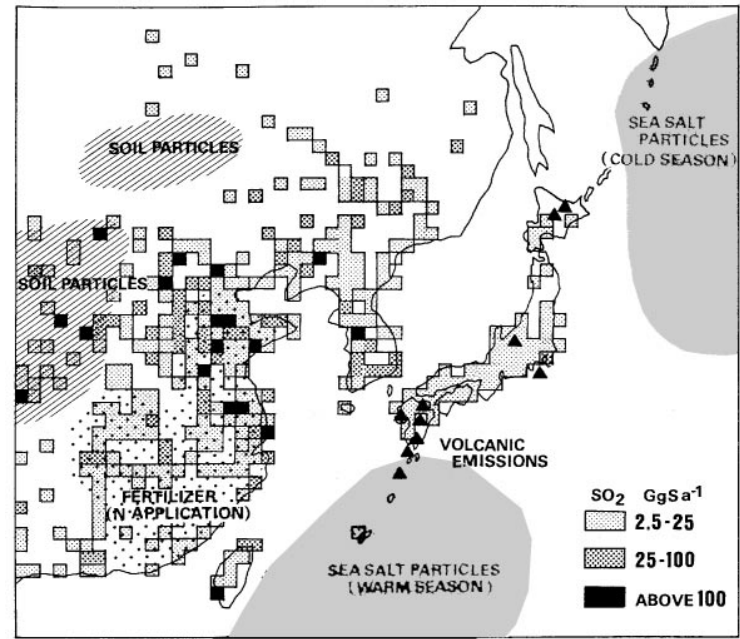

Fig. 5. Annual emissions of sulfur dioxide per grid square as of 1990 superimposed on the geographical distribution of production sources of sea salt, volcanic sulfur, soil particles, and ammonia in East Asia.

Volcanic emissions of sulfur account for less than $5 \%$ of the total emission in East Asia. Although the geographical distributions of emission sources of nitrogen oxides and sulfur dioxide are almost the same, major sources of nitrogen are located separately within several metropoli$\tan$ areas. Therefore, although the effects of volcanoes may be taken into account as occasional sources, concentration of $\left[\mathrm{nssSO}_{4}^{2-}+\mathrm{NO}_{3}^{-}\right]$in precipitation can be used as an index to demonstrate the effect of human activities in East Asia.

Sulfuric acid and nitric acid are subjected to neutralization to some extent before being deposited on the ground surface. As shown in Table $1, \mathrm{nssCa}^{2+}$ and $\mathrm{NH}_{4}^{+}$ account for the major portion of non-sea salt cations in precipitation. Calcium is also emitted into the atmosphere through production and combustion processes. Emissions of calcium from cement factories in the Beijing area (Hao, 1991) and the abrasion of roads in areas of heavy snowfall in Japan (Noguchi, 1995) should also be considered. Nevertheless, as shown in Fig. 5, the major broad emission source of calcium is considered to be located in the deserts of the continent. The major emission sources of atmospheric ammonia are agricultural activities on the continent (Zhao and Wang, 1994); the level of ammonia emission from Japan and Korea is lower (Murano et al., 1996). Because the broad production sources of both calcium and ammonia are on the continent, concentration of $\left[\mathrm{nssCa}^{2+}+\mathrm{NH}_{4}^{+}\right]$in precipitation may be used as an index to demonstrate the effect of air masses of continental origin.

The regions of ocean that experience relatively high wind speeds are also areas of high atmospheric sea salt 
production. As shown in Table $1, \mathrm{Na}^{+}$and $\mathrm{Cl}^{-}$account for the major portion of the sea salt ions in precipitation. The composition of precipitation in coastal regions is dominated by the presence of $\mathrm{NaCl}$, the concentration of which decreases exponentially with distance from the coast. Beyond $100 \mathrm{~km}$ from the coast, the concentration levels off at about $30 \mu \mathrm{mol} \mathrm{l}^{-1}$ (Brimblecombe, 1996). The average concentration of $\mathrm{Cl}^{-}$and $\mathrm{Na}^{+}$at Beijing and Jinan is approximately $65 \mu$ eq $1^{-1}$, which is lower than $25 \%$ of the average concentration at 11 sites in Japan $\left(290 \mu\right.$ eq $\left.1^{-1}\right)$. As shown in Fig. 5, the broad production source of sea salt is considered to be the northwestern Pacific in the cold season and the centralwestern Pacific in the warm season, concentration of $\left[\mathrm{Cl}^{-}+\mathrm{Na}^{+}\right]$in precipitation may be used as an index to demonstrate the effects of air-masses of oceanic origin.

As mentioned above, the major soluble ions in precipitation are $\mathrm{SO}_{4}^{2-}, \mathrm{NO}_{3}^{-}, \mathrm{Ca}^{2+}, \mathrm{NH}_{4}^{+}, \mathrm{Na}^{+}$, and $\mathrm{Cl}^{-}$in East Asia, the three indexes $\left[\mathrm{nssSO}_{4}^{2-}+\mathrm{NO}_{3}^{-}\right]$, $\left[\mathrm{nssCa}{ }^{2+}+\mathrm{NH}_{4}^{+}\right]$, and $\left[\mathrm{Na}^{+}+\mathrm{Cl}^{-}\right]$may be used to evaluate the origin in terms of the air mass and the qualitative characteristics of ions in precipitation. Tsuruta (1989) defined the value of $\left[\mathrm{nssSO}_{4}^{2-}+\mathrm{NO}_{3}^{-}\right]$ as acidifying potential $\mathrm{AP}$ and that of $\left[\mathrm{nssCa}^{2+}+\mathrm{NH}_{4}^{+}\right]$ as neutralizing potential NP, and discussed the qualitative differences in precipitation between Japan, China, and the United States. Here, AP is identical to the "input acidity" defined by Morgan (1982). Hara (1993) defined the value of $-\log \left[\mathrm{nssSO}_{4}^{2-}+\mathrm{NO}_{3}^{-}\right]$as "pAi" and discussed the difference in latent acidity of precipitation between various locations. Fig. 6 shows the relationship between annual averages of AP and NP at various sites. The solid lines pDi, defined here as $-\log \mathrm{Di}$, where $\mathrm{Di}=\left[\mathrm{nssSO}_{4}^{2-}+\mathrm{NO}_{3}^{-}\right]-\left[\mathrm{nsSCa}^{2+}+\mathrm{NH}_{4}^{+}\right]$, can be used as an index for the acidity of precipitation.

As shown in Fig. 6, the relationship NP $>$ AP holds at Beijing and Jinan in northeastern China. Although the value of AP is high, that of NP is higher. This relationship is maintained throughout the year. This means that the amounts of ammonia and airborne particles (for example, $\mathrm{CaCO}_{3}$ ), sufficient to neutralize acids, are constantly produced through natural and anthropogenic activities on the continent. The higher concentrations of these bases in the atmosphere are incorporated into cloud droplets or falling precipitation and neutralize some of the precipitation acidity caused by $\mathrm{H}_{2} \mathrm{SO}_{4}$ and $\mathrm{HNO}_{3}$ from fossil fuel combustion. Consequently, although northeastern China has the largest emission sources of $\mathrm{SO}_{2}$, precipitation with relatively high $\mathrm{pH}$ value is observed throughout the year. If bases were not present in the atmosphere, the annual average value of original $\mathrm{pH}$ would be about 3.4 for Beijing and 3.5 for Jinan.

Conversely, the relationship $\mathrm{NP}<\mathrm{AP}$ holds at Hachijo and Amami in the Pacific Ocean. Although the value of AP is low, that of NP is lower. This relationship is maintained throughout the year. Therefore, although

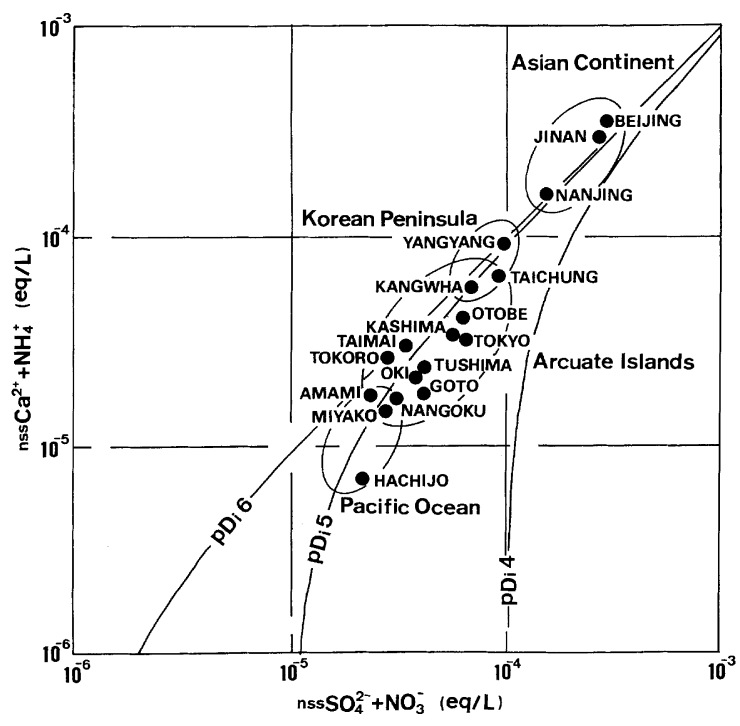

Fig. 6. Relationship between annual averages of AP $\left(=\left[\mathrm{nsSSO}_{4}^{2-}+\mathrm{NO}_{3}^{-}\right]\right)$and $\mathrm{NP}\left(=\left[\mathrm{nssCa}^{2+}+\mathrm{NH}_{4}^{+}\right]\right)$at various sites in East Asia. Solid lines indicate the values of $\mathrm{pDi}$ $(=-\log \mathrm{Di})$, where $\mathrm{Di}=\mathrm{AP}-\mathrm{NP}$.

Hachijo and Amami are located more than $1000 \mathrm{~km}$ from the major $\mathrm{SO}_{2}$ and $\mathrm{NO}_{x}$ emission sources in East Asia, precipitation with relatively low $\mathrm{pH}$ value is observed throughout the year. If bases were not present in the atmosphere, the annual average value of the original $\mathrm{pH}$ would be 4.7 for Hachijo and 4.6 for Amami. The ratio $\mathrm{NP} / \mathrm{AP}$ in precipitation was highest in northern China (1.19 for Beijing), moderate in the Korean Peninsula (0.83 for Kangwha) and the Japanese Islands ( 0.57 for Kashima and 0.52 for Tokyo), and lowest in the northern Pacific ( 0.30 for Hachijo). This ratio decreased exponentially with distance from the continent to ocean, indicating that the average residence time differs between bases $\left(\mathrm{NH}_{3}+\mathrm{CaCO}_{3}\right)$ and acid gases $\left(\mathrm{SO}_{2}+\mathrm{NO}_{x}\right)$ in the lower atmosphere.

Fig. 7 shows the relationship between the annual averages of NP and $\mathrm{SP}\left(=\left[\mathrm{Na}^{+}+\mathrm{Cl}^{-}\right]\right)$at various sites. The relationship NP $>$ SP holds in the Asian continent, $\mathrm{NP} \fallingdotseq \mathrm{SP}$ in the Korean Peninsula, and $\mathrm{NP}<\mathrm{SP}$ in the Arcuate Islands and the northern Pacific. This means that the ionic concentrations of the precipitation in Korean Peninsula is affected by both continental dry air masses and subtropical humid air masses, depending on the meteorological conditions.

To clarify the relationship between ionic concentrations in precipitation and meteorological conditions characterized by monsoon, subtropical, and temperate climates, we now focus on the precipitation pattern as well as the upper wind system in East Asia. Fig. 8 shows the distribution of annual precipitation in East Asia and the position of air mass (vector average for each month) 


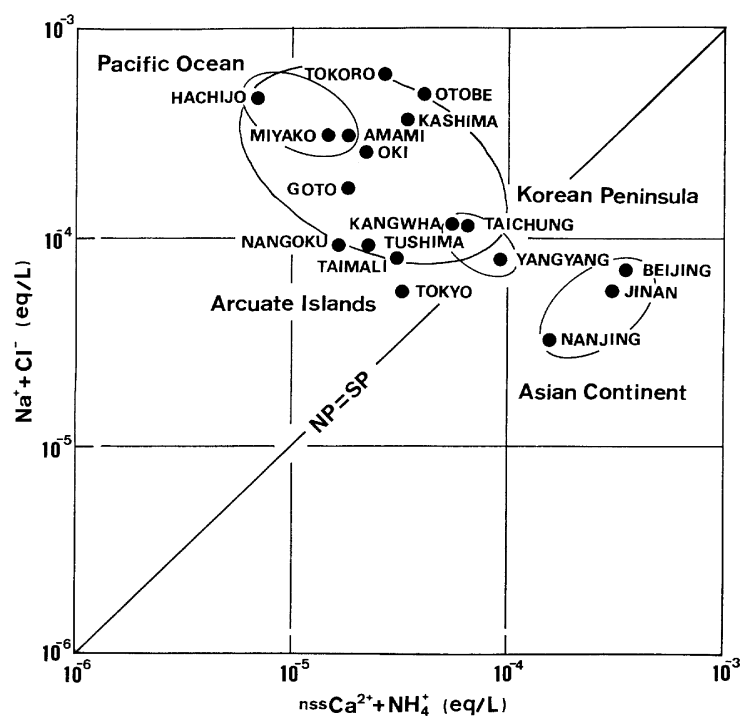

Fig. 7. Relationship between annual averages of NP $\left(=\left[\mathrm{nssCa}^{2+}+\mathrm{NH}_{4}^{+}\right]\right)$and $\mathrm{SP}\left(=\left[\mathrm{Na}^{+}+\mathrm{Cl}^{-}\right]\right)$at various sites in East Asia.

$24 \mathrm{~h}$ before arrival at the $850 \mathrm{hPa}$ isobaric surface over Tushima, center of the monitoring region. The annual precipitation in East Asia tends to be high in the southeastern region and low in the northwestern region, excluding the northwest coast of Japan. The southeast coasts of Japan and Taiwan receive more than $3000 \mathrm{~mm}$ of rainfall per year, while the interior of Mongolia received less than $200 \mathrm{~mm}$. With respect to seasonal changes, the monthly precipitation is generally high in summer under the warm humid air masses, and low in winter under the cold dry air masses. Little data is available concerning annual precipitation over the ocean.

As shown in Fig. 8, the predominant wind system over East Asia varies depending on the season. In the warm season, in which the subtropical high-pressure system over the Pacific is dominant, the direction of wind at Tushima may be from the East China Sea or the Pacific Ocean. In the cold season, the predominant wind system over Tushima is northwesterly, from the continent to the East China Sea and the Korean Peninsula. The run of wind during the period between December and February is particularly long.

As shown in Fig. 4, a high concentration of sulfate in precipitation is frequently observed in winter season at sites on the Sea of Japan side. This is explained by the fact that strong northwesterly wind from the Siberian highpressure system over the continent carries a dry air mass over the sea. This air mass receives moisture, and becomes unstable as it passes over the Sea of Japan. When the wet air reaches the central mountain range of the Japanese Islands, heavy snowfall results on the Sea of

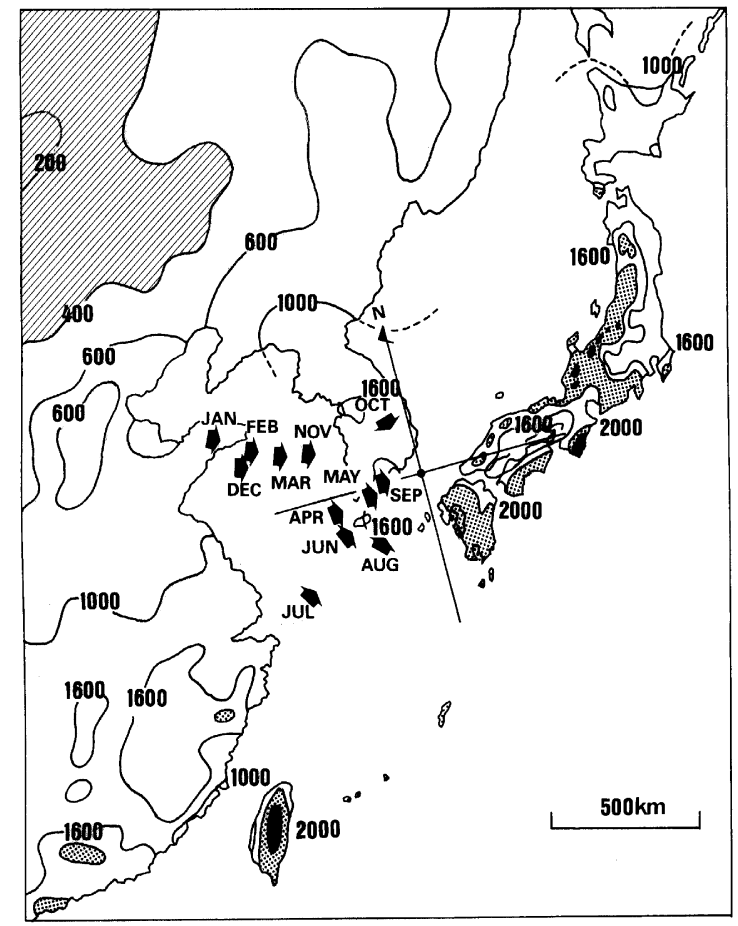

Fig. 8. Annual amounts of precipitation in East Asia (solid line) and the positions of air mass (vector average for each month) $24 \mathrm{~h}$ before arrival at the $850 \mathrm{hPa}$ isobaric surface over Tsushima (solid circles).

Japan side. Sulfur compounds emitted from the continent and carried over the sea are incorporated into snow clouds in this process. Since the production of sea salt is directly related to wind speed, sea salt sulfate produced from the sea are also incorporated into snow clouds or scavenged by snow flakes below cloud layers, and deposited with non-sea salt sulfate on the Sea of Japan side. After losing part of its sulfur content in this way, the dry air mass passes over the central mountain range to the Pacific Ocean.

Although there are various complex causes of precipitation in East Asia; the wet deposition is basically a flux that is determined as the product of the ionic concentration and the amount of precipitation. Therefore, as shown in Table 1 and Fig. 3, the wet deposition of nssSO ${ }_{4}^{2-}, \mathrm{NO}_{3}^{-}, \mathrm{nssCa}^{2+}$, and $\mathrm{NH}_{4}^{+}$, which showed high concentrations on the continent and low concentrations over the ocean, was canceled by precipitation, which showed low amounts on the continent and high amounts over the ocean, resulting in relatively small differences between the sites. Conversely, the wet deposition of $\mathrm{Na}^{+}$, and $\mathrm{Cl}^{-}$, which showed high concentrations over the ocean and low concentrations in the continents, was amplified by precipitation, which showed high amounts over the ocean and low amounts on the continent, 
resulting in relatively large differences between the sites in East Asia.

\section{Conclusions}

Factors controlling the chemical composition of precipitation in East Asia were analyzed on the basis of the results of cooperative monitoring at 18 sites between June 1992 and May 1993. The major soluble ions in this region were $\mathrm{SO}_{4}^{2-}, \mathrm{NO}_{3}^{-}, \mathrm{Ca}^{2+}, \mathrm{NH}_{4}^{+}, \mathrm{Na}^{+}$, and $\mathrm{Cl}^{-}$. The wet deposition of soluble ions was characterized by two major factors: meteorological conditions such as wind system and rainfall pattern due to the Asian monsoon, and the geographical distribution of precursor production through natural and anthropogenic activities. Although the origins of these ions have not yet been clarified completely, it was considered that $\mathrm{nssSO}_{4}^{2-}$ and $\mathrm{NO}_{3}^{-}$mainly originated from industrial activities, $\mathrm{nssCa}^{2+}$ and $\mathrm{NH}_{4}^{+}$mainly originated from the continent; and $\mathrm{Na}^{+}$and $\mathrm{Cl}^{-}$mainly originated from the ocean.

Since the origins of ions were geographically classified as the continent and the ocean, three indexes of AP $\left[\mathrm{nssSO}_{4}^{2-}+\mathrm{NO}_{3}^{-}\right]$, NP $\left[\mathrm{nssCa}^{2+}+\mathrm{NH}_{4}^{+}\right]$, and $\mathrm{SP}$ $\left[\mathrm{Na}^{+}+\mathrm{Cl}^{-}\right]$could be used to evaluate the qualitative characteristics of precipitation in East Asia. In northeastern China, the value of AP was high, that of NP was higher. It was suggested that amounts of ammonia and airborne calcium sufficient to neutralize acids were constantly produced through natural and anthropogenic activities in this region. The higher concentrations of these bases in the atmosphere were incorporated into precipitation elements and neutralized some of the precipitation acidity caused by $\mathrm{H}_{2} \mathrm{SO}_{4}$ and $\mathrm{HNO}_{3}$ from fossil fuel combustion. Consequently, although northeastern China has the largest anthropogenic emission source, precipitation with relatively high $\mathrm{pH}$ value was observed. Conversely, at islands in the northern Pacific, the value of AP was low, that of NP lower. Therefore, although these islands are located far from the major anthropogenic emission sources, precipitation with relatively low $\mathrm{pH}$ value was observed. The ratio of $\mathrm{NP} / \mathrm{AP}$ was highest in northeastern China, moderate in the Korean Peninsula and the Japanese Islands, and lowest in the northern Pacific. The finding that this ratio decreases with distance from the continent, might reflect the difference in the average residence time between bases and acid gases in the lower atmosphere.

In the central part of East Asia, ionic concentrations of precipitation were affected by both continental cold and dry air masses and subtropical warm and humid air masses. Thus, $\mathrm{pH}$ of precipitation showed a broad distribution in which both effects were superimposed. The wet deposition of nssSO ${ }_{4}^{2-}, \mathrm{NO}_{3}^{-}, \mathrm{nssCa}^{2+}$, and $\mathrm{NH}_{4}^{+}$, which showed high concentrations on the continent and low concentration over the ocean, was canceled by precipita- tion, which showed low amounts on the continent and high amounts over the ocean, resulting in relatively small differences between the sites. Conversely, the wet deposition of $\mathrm{Na}^{+}$and $\mathrm{Cl}^{-}$, which showed high concentrations over the ocean and low concentrations in the continents, was amplified by precipitation, which showed high amounts over the ocean and low amounts on the continent, resulting in relatively large differences between the sites in East Asia.

\section{Acknowledgements}

The authors would like to thank Prof. Yoshikazu Hashimoto, Prof. Yoshiaki Iwasa, Prof. Qi-Shun Zhang, Ms. Yueh-Yuan Tu, Mr. Hideo Tabata, and Mr. Hiroshi Shikata for advice on establishing the first monitoring network for precipitation chemistry in East Asia. Part of this program was carried out under a contract with the Ministry of International Trade and Industry, Japan.

\section{References}

Ayers, G., Gillett, R., Hara, H., 1997. Acidic deposition in East Asia and Oceania. In: Whelpdale, D. M., Kaiser, M. S. (Eds.), Global Acid Deposition Assessment. World Meteorological Organization Global Atmosphere Watch No. 106, 107-134.

Akimoto, H., Narita, H., 1994. Distribution of $\mathrm{SO}_{2}, \mathrm{NO}_{x}$ and $\mathrm{CO}_{2}$ emissions from fuel combustion and industrial activities in Asia with $1^{\circ} \times 1^{\circ}$ resolution. Atmospheric Environment 28A, 213-225.

Brimblecombe, P., 1996. Air Composition \& Chemistry. 2nd Edition. Cambridge University Press, Cambridge, 253 pp.

Chen, C. S., Lin, N. H., Peng, C. M., Jeng, F. T., 1996. Acidic deposition on Taiwan and associated precipitation system. International Conference on Acid Deposition in East Asia. Taipei, Taiwan, 28-30 May 1996, pp. 124-132.

CRIEPI (Central Research Institute of Electric Power Industry), 1993. International Workshop on Acidic Deposition in East Asia: extended abstracts. 24-26 November 1993. Hakone, Japan, 63 pp.

Dokiya, Y., Miyakoshi, N., Hirooka, T., Yamashita, J., Ishikawa, S., Ohya, M., Sugaya, J., 1995. Long range transport of sulfur compounds over the Western North Pacific: Deposition samples obtained on islands. Journal of Meterological Society of Japan 73, 873-881.

Erickson, D.J., Duce, R.A., 1988. On the global flux of atmospheric sea salt. Journal of Geophysical Research 93, 14079-14088.

Fujita, S., Ichikawa, Y., Kawaratani, R.K., Tonooka, Y., 1991. Preliminary inventory of sulfur dioxide emissions in East Asia. Atmospheric Environment 25A, 1408-1409.

Fujita, S., Tonooka, Y., Ohta, K., 1992. Annual contribution of volcanic sulfur emissions on the atmosphere in Japan. Journal of Japan Society of Air Pollution 27, 336-343.

Fujita, S., Takahashi, A., 1994. Acidic deposition in East Asia; design of the cooperative monitoring network for the chemistry of precipitation. CRIEPI Rep. No. T93091, pp. 35. 
Fujita, S., 1997. Overview of Acid deposition assessment program in CRIEPI. Proceedings of the CRIEPI International Seminar on Transport and Effects of Acidic Substances, 28-29 November 1996, CRIEPI, Tokyo, Japan, pp. 29-38.

Galloway, J.N., Zhao, D., Xinng, J., Likens, G.E., 1987. Acid rain: China, United States, and remote area. Science 236, 1559-1562.

Hao, Q., 1991. Present status of the acid rain problem in China and tasks for the period. Journal of Japan Society of Air Pollution 26, 283-291.

Hao, Q., 1993. The study on the sand/dust storms in northwest China and high-altitude transportation path of Kosa aerosol. Environmental Science 14, 43-50.

Hara, H., 1993. Acid deposition chemistry in Japan. Bulletin of the Institution of Public Health 42, 1-12.

Hseung, Y., Jackson, M.L., 1952. Mineral composition of the clay fraction of some main soil groups of China. Soil Science Society of American Proceedings 16, 97-110.

Ishikawa, Y., Hara, H., 1997. Historical change in precipitation pH at Kobe, Japan: 1935-1961. Atmospheric Environment 31 (15), 2367-2369.

Ichikawa, Y., Hayami, H., Fujita, S., 1997. Development of longrange transport models for East Asia. Proceedings of the CRIEPI International Seminar on Transport and Effects of Acidic Substances, 28-29 November 1996, CRIEPI, Tokyo, Japan, pp. 67-76.

Ichikuni, M., 1978. Calcite as source of excess calcium in rainwater. Journal of Geopysical Research $83 \mathrm{C} 12$, 6249-6252.

JEA (Japan Environment Agency), 1987. Interim Report of Acid Precipitation Survey in Japan. JEA, 19 pp.

Jeng, F. T., 1995. Annual Report, EPA-84-E3F 1-09, Environmental Protection Administration of Taiwan, Taipei, Taiwan, 101pp.

Katoh, T., Konno, T., Koyama, I., Tsuruta, H., Makino, H., 1989. Acidic precipitation in Japan. In: Bresser, A.H.M., Salomons, W. (Eds.), Acidic Precipitation, vol. 5, International Overview and Assessment, Springer, Berlin, pp. 41-105.

Kawaratani, R.K., Fujita, S., 1990. Wet deposition of volcanic gases and ash in the vicinity of Mount Sakurajima. Atmospheric Environment 24A, 1487-1492.

Kellner, O., Sawano, J., Yoskii, T., Makino, R., 1886. Mittheilungen aus dem Agrikulturchemischen Laboratorium des Kaiserl Japanischen Landwirthschaftlichen Instituta zu Tokio, I. Untersuchungen uber den Gehalt der Atmospharischen Niederschlage an Stickstoffverbindungen. Landw. Jahrbuhr 15, 701-708.

Kim, H. K., 1997. Air pollution research and monitoring of wet deposition in Korea. Proceedings of the CRIEPI International Seminar on Transport and Effects of Acidic Substances, 28-29 November 1996, CRIEPI, Tokyo, Japan, pp. 29-38.

Kitamura, M., Katou, T., Sekiguchi, K., Taguchi, K., Tamaki, M., Oohara, M., Mori, A., Murano, K., Wakamatsu, S., Yamanaka, Y., Okita, T., Hara, H., 1991. pH and its frequency patterns of acid precipitation in Japan. Journal of Chemical Society Japan 6, 913-919.

Köppen, W., 1936. Das Geographische System der Klimate. Handbuch der Klimatologie, Band 1, Teilc, 44p.
Lee, M.H., Han, J.S., Han, E.J., Shin, C.K., 1989. A study on the chemical composition of precipitation during the period of sandy dust phenomena. Journal of Korea Air Pollution Research Association 5, 1-11.

Lee, M. H., 1996. Situation of acid rain in Korea. In: Hirai, E. (Ed.), Strategy for Air Pollution Control in East Asia. International Symposium on the Air Pollution Control Policy and Strategy, Chongqing, China, 1992, pp. 25-30.

Miles, L.M., Yost, K.J., 1982. Quality analysis of USGS precipitation chemistry data for New York. Atmospheric Environment 18, 2889-2898.

Miller, N.H.J., 1913. The composition of rain-water collected in the Hebrides in Iceland; With special reference to the amount of nitrogen as ammonia and as nitrates. Scottish Meterological Society XVI, 141-158.

Morgan, J.J., 1982. Factors governing the $\mathrm{pH}$, availability of $\mathrm{H}^{+}$, and oxidation capacity of rain. In: Goldberg, E.D. (Ed.), Atmospheric Chemistry. Springer, Berlin, pp. 17-40.

Murano, K., Hatakeyama, S., Kuba, N., Lee, D. S., Lee, T. Y., 1996. Grid ammonia emission fluxes in Japan and Korea. Proceeding of the International Symposium on Acid Deposition and its Impact. 10-12, December 1996, Tsukuba, Japan, pp. 134-140.

Nishikawa, M., Kanamori, S., Kanamori, N., Mizoguchi, T., 1991. Ion equivalent balance in water soluble constituents of Kosa aerosol. Journal of Aerosol Research in Japan 6, 157-164.

Noguchi, I., Kato, T., Akiyama, M., Otsuka, H., Matumoto, Y., 1995. The effect of alkaline dust decline on the precipitation chemistry in northern Japan. Water, Air and Soil Pollution 85, 2357-2362.

Ohizumi, T., Fukuzaki, N., Moriyama, N., Urushiyama, Y., Kusakabe, M., 1991. Source of sulfur in the atmospheric deposits in view of sulfur isotopic variations. Journal of the Chemical Society of Japan 5, 675-681.

Okada, K., Kai, K., 1995. Features and elemental composition of mineral particles collected in Zangye. China. Journal of Meterological Society of Japan 73, 947-957.

Okita, T., 1983. Acid precipitation and related phenomena in Japan. Water Quality Bulletin 8, 101-108.

Tamaki, M., Koyama, I., 1991. The acid rain observed on ground level in Japan; A Review of major issues and problems. Journal of Japan Society for Air Pollution 26, $1-22$.

Toriyama, S., Shimada, H., Arakawa, H., Tanaka, T., Tohezou, Y., 1991. Precipitation chemistry in Toyama. Japanese Journal of the Society of Chemistry in Japan 5, 682-689.

Tsuruta, H., 1989. Acid precipitation in Eastern Asia. Kagaku 59, 305-315.

Trewartha, G. A., Robinson, A. H., Hammond, E. H., 1967. Elements of Geography. New York.

Uematsu, M., Duce, R.A., Prospero, J.M., Chen, L., Merrill, J.T., McDonald, R.L., 1983. Transport of mineral aerosol from Asia over the North Pacific Ocean. Journal of Geophysical Research 88, 5343-5352.

Weng, J. H., 1993. Study on acidic deposition in Beijing. Water Quality Research Centre, China, 53 pp.

WMO (World Meteorological Organization) 1978. International Operations Handbook for Measurement of Background Atmospheric Pollution, Rep. 491, WMO, Geneva. 
WMO (World Meteorological Organization) 1997. Global acid deposition assessment. In: Whelpdale, D. M., Kaiser, M. S. (Eds.), WMO Global Atmosphere Watch No. 106, pp. 241.

Yamaguchi, K., Tatano, T., Tanaka, F., Nakao, M., Gomyoda, M., 1991. An analysis of precipitation chemistry measurements in Shimane, Japan. Atmospheric Environment 25A, 285-291.
Zhao, D., Xiong, J., Xu, Y., Chan, W.H., 1988. Acid rain in southwestern China. Atmospheric Environment 22, 349-358.

Zhao, D., Wang, A., 1994. Estimation of anthropogenic ammonia emissions in Asia. Atmospheric Environment 28A, 689-694. 